\title{
Notas sobre a bionomia de Trichotrigona extranea Camargo \& Moure (Hymenoptera, Apidae, Meliponini)
}

\author{
João M. F. Camargo ${ }^{1,2} \&$ Silvia R. M. Pedro ${ }^{1}$
}

'Departamento de Biologia, Faculdade de Filosofia, Ciências e Letras de Ribeirão Preto, Universidade de São Paulo, Av. Bandeirantes, 3900, 14040-901 Ribeirão Preto-SP, Brasil.jmafcama@ffclrp.usp.br

${ }^{2}$ Pesquisador do $\mathrm{CNPq}$

\begin{abstract}
Notes on the bionomy of Trichotrigona extranea Camargo \& Moure (Hymenoptera, Apidae, Meliponini). Three nests of T. extranea, found in "igapó" forests in the locality of Samaúma, mouth of Daraã river $\left(64^{\circ} 45^{\prime} 35^{\prime \prime} \mathrm{W}\right.$, $\left.0^{\circ} 27^{\prime} 7^{\prime \prime} \mathrm{S}\right)$, AM, Brazil, are described and illustrated. This is the only place from where this species is known. All nests were located in hollow of dried branches of "Tanimbuca" - Buchenavia suaveolens Eichler (Combretaceae). Two of them were sharing the hollow with nests of Frieseomelitta sp. and one was solitary. One nest had 46 brood cells, 43 adult workers and one physogastric queen; the second one, 240 cells, 117 adult workers, 25 males and one physogastric queen; the third one, 260 cells, 163 workers, one physogastric queen and one queen pupa. The cells are arranged in clusters, like in Frieseomelitta, and the queen cells has the same shape and size as the worker ones. There are no food pots - this is the only known Meliponini that does not store food. Supposedly, this species is cleptobiotic. Queens and males are also described.
\end{abstract}

KEYWORDS. Cleptobiosis; nest; stingless bees; Trichotrigona.

RESUMO. Notas sobre a bionomia de Trichotrigona extranea Camargo \& Moure (Hymenoptera, Apidae, Meliponini). Três ninhos de T. extranea, encontrados nas matas de igapó, na localidade de Samaúma, foz do rio Daraã $\left(64^{\circ} 45^{\prime} 35^{\prime \prime}\right.$ W, $\left.0^{\circ} 27^{\prime} 7^{\prime \prime} \mathrm{S}\right), \mathrm{AM}$, Brasil, são descritos e ilustrados. Este é o único lugar onde esta espécie é conhecida. Todos os ninhos estavam em ocos de ramos secos de "Tanimbuca" - Buchenavia suaveolens Eichler (Combretaceae). Dois deles compartilhavam o oco com ninhos de Frieseomelitta sp. e um era solitário. Um ninho continha 46 células de cria, 43 operárias adultas e uma rainha fisogástrica; o segundo, 240 células, 117 operárias, 25 machos e uma rainha fisogástrica; o terceiro, 260 células, 163 operárias, uma rainha fisogástrica e uma pupa de rainha. As células são construídas na forma de cacho, como em Friseomelitta, e as células de rainha são do mesmo tamanho e forma que as de operária. Não há potes de alimento - este é o único Meliponini que se conhece que não armazena alimento. Supostamente, esta espécie tem hábitos cleptobióticos. Rainhas e machos são também descritos.

PALAVRAS-CHAVE. abelhas-sem-ferrão; cleptobiose; ninho; Trichotrigona.

$\mathrm{Na}$ ocasião em que o primeiro ninho desta espécie foi descoberto (em 4 de agosto de 1980, por Camargo e Mazucato), supôs-se que se tratava de um ninho novo, em fase de consolidação - visto que continha apenas algumas células e casulos, uma rainha sem desgaste alar e algumas operárias, e não havia potes de alimento -, ou que estava incompleto, ou seja, que parte havia sido perdida durante a retirada do tronco (Camargo \& Moure 1983). Havia, ainda, a suspeita de que esta espécie pudesse ser um parasita social, conforme sugerido por Roubik (1989) e Michener (1990: 128; 2000: 799), considerando que as operárias não apresentam pente na tíbia III e o penicilo é bastante reduzido, e também o fato de que o primeiro ninho encontrado estava anexo a um ninho de Frieseomelitta paranigra (Schwarz, 1940).

Agora, em uma expedição mais recente ao longo do rio Negro (julho-agosto de 1999 - Camargo, Pedro e Mazucato), três outros ninhos foram descobertos e, assim, alguns aspectos interessantes sobre o modo de vida destas abelhas puderam ser esclarecidos.

Também, o texto original de Camargo \& Moure (1983) onde se descreve Trichotrigona, saiu com vários erros e muitas falhas, principalmente editoriais, e esta é a oportunidade para corrigi-los, em adição às descrições dos ninhos, rainhas e machos.

Sobre as relações filogenéticas deste gênero, há as hipóteses apresentadas por Camargo \& Pedro (2003), que posicionam Trichotrigona como grupo-irmão de Duckeola Moure, 1944 + Frieseomelitta Ihering, 1912.

\section{MATERIALE MÉTODOS}

Foram estudados três ninhos de Trichotrigona extranea Camargo \& Moure, 1983, todos provenientes da localidade de Samaúma, junto a foz do rio Daraã, AM (644' $\left.35^{\prime \prime} \mathrm{W}, 0^{\circ} 27^{\prime} 7^{\prime \prime S}\right)$. Os ninhos receberam os números 800 c, 806 e e 807 c; foram abertos diretamente no campo, onde foram feitos desenhos, fotos e anotações sobre aspectos da bionomia. Toda a população dos ninhos, inclusive as células de crias, foi coletada. Do total de indivíduos adultos coletados, 351 dos três ninhos juntos, 173 operárias e 18 machos foram montados em alfinetes; os demais, incluindo as rainhas, sete machos, operárias e as células de cria, foram preservados em via líquida (alguns em álcool 100\%, outros em Dietrich por 48 horas e depois álcool 70\%). 
Os galhos que continham os ninhos e todo o material preservado, se encontram depositados na Coleção do Departamento de Biologia da Faculdade de Filosofia, Ciências e Letras de Ribeirão Preto - Universidade de São Paulo (RPSP - Coleção Camargo), exceto os seguintes exemplares doados: 3 operárias na Coleção de Entomologia do Instituto Nacional de Pesquisas da Amazônia (INPA), 2 operárias no Smithsonian Tropical Research Institute, Panamá (D. Roubik) e 3 operárias no Illinois Natural History Survey, Insect Collection, UrbanaChampaign, Illinois, EUA (INHS, C. Favret e S. Cameron).

As exsicatas das plantas hospedeiras dos ninhos estão depositadas no herbário - INPA, bem como as amostras de pólen obtidas das células de cria, estão na Palinoteca dessa mesma Instituição.

Sobre a diagnose do gênero e descrição da espécie. A diagnose abaixo é uma reprodução do texto original de Camargo \& Moure (1983), com as devidas correções dos erros e falhas editoriais, acrescido do item $\mathbf{l}$, referente à tíbia anterior, e com os caracteres autapomórficos destacados em negrito. $\mathrm{Na}$ reprodução da descrição da espécie, os dois trechos, que no original foram trocados de posição, são recolocados na devida seqüência. As medidas são apresentadas em milímetros. Também, uma nova lista sobre o destino dos exemplares da série-tipo é apresentada.

\section{Trichotrigona Camargo \& Moure, 1983}

Trichotrigona Camargo \& Moure, 1983: 421

Espécie-tipo: Trichotrigona extranea Camargo \& Moure, 1983: 424 (por designação original)

a) Integumento liso e polido; pontuação pilígera esparsa, com intervalos maiores (3 a 4 diâmetros) que os pontos; manchas amarelas: na cabeça bem evidentes, destacando-se uma faixa ao redor das órbitas, interrompida no terço ânterosuperior (Fig. 1); no tórax, bem delineadas aos lados do mesoscuto e obsoletas nas axilas e bordo posterior do escutelo. b) Olhos compostos com pilosidade ereta bem evidente, quase tão longa como aquela das paroculares (0,04-0,05 mm de comprimento) (Fig. 1). c) Cabeça levemente mais estreita que o tórax; distância máxima interorbital $(1,44)$ maior que o comprimento do olho $(1,25)$; órbitas internas levemente sinuosas e convergentes embaixo; tangente alveolar superior nitidamente acima do meio da face $(0,61)$; distância interalveolar um pouco maior que a metade da alveolorbital (0,20:0,38); parte mediana da fronte levemente deprimida, a superior abaulada e a inferior elevada entre os alvéolos das antenas; sem carena frontal. d) Clípeo levemente arqueado; pilosidade baixa sem cerdas destacadas; duas vezes mais largo que longo; sutura epistomal, aos lados, levemente encurvada. e) Mandíbulas bidentadas no terço interno; os dentes pequenos e agudos; o intervalo entre eles em semicírculo. f) Vértice convexo, pouco elevado acima da tangente orbital superior; sem carenas preoccipitais; a distância oceloccipital $(0,30), 1,5$ vezes o diâmetro do ocelo médio ( 0,20$)$; a orbitoccipital $(0,40), 1,3$ vezes a oceloccipital; a interocelar $(0,48)$ um pouco maior que duas vezes o diâmetro do ocelo médio; a ocelorbital $(0,32)$ dois terços da interocelar. g) Escapo uma vez e meia mais longo que a distância alveolocelar lateral (Fig. 1); artículos do flagelo um pouco mais longos que o seu diâmetro; o segundo artículo um pouco mais longo que o primeiro e igualando o terceiro. h) Suturas prescutais e sulco médio fracos; escutelo nitidamente projetado além do metanoto. i) Asas anteriores mais longas que o corpo e notavelmente pilosas; pterostigma pequeno, parastigma mais curto que a largura do pterostigma; célula marginal quatro vezes e meia mais longa que larga, estreitada na base e quase fechada no ápice; bifurcação da $\mathrm{Cu}-\mathrm{M}$ anterior a cu-an; ângulo submarginal aberto; veia Média forte, formando ângulo na primeira m-cu e indo até quase o bordo distal da asa; células submarginais praticamente nulas; Cubital evidente; hâmulos 6; lóbulo jugal metade do comprimento do lóbulo anal; veias $\mathrm{M}$ e cu-an, ausentes na asa posterior. j) Tíbia posterior alargado-claviforme; bordo posterior ligeiramente côncavo no terço basal, o anterior fracamente convexo; canto póstero-distal inteiramente arredondado; pêlos da margem posterior simples, longos e curtos intercalados; alguns plumosos na margem distal; área "corbicular" grande, pilosa, aproximadamente $3 / 5$ do comprimento da tíbia (Fig. 4); elevação média interna quirotriquiada mais estreita que a expansão posterior; esta com pilosidade mais longa e esparsa; penicilo reduzido; pente ausente. $k$ ) Basitarso posterior chato, sua largura aproximadamente 1/3 do seu comprimento; lados paralelos; margem distal em ângulo obtuso de vértice arredondado (Fig. 4); superfície interna uniformemente pilosa. l) Tíbia anterior da operária, intumescida e revestida, na face externa, por cerdas longas, rijas e espatuladas no ápice (Fig. 7). m) Propódeo bem desenvolvido, abaulado; área basal glabra, lisa, brilhante, aos lados com alguns pêlos; abdômen robusto, tão largo quanto o tórax; último tergo terminando em ponta.

Na diagnose original, por um lapso, não foi incluída uma das principais autapomorfias do gênero, referente às cerdas espatuladas da tíbia anterior, conforme descrito no item $\mathbf{l}$. Penicilo reduzido e pente ausente (item i), são caracteres apomórficos-homoplásticos. A redução ou perda dessas estruturas ocorre independentemente em outros Meliponini; por exemplo, nas espécies de Lestrimelitta Friese, 1903, tanto o penicilo como o pente são totalmente perdidos.

\section{Trichotrigona extranea Camargo \& Moure, 1983}

(Figs. 1, 4 e 7)

Trichotrigona extranea Camargo \& Moure, 1983: 424

Operária.

Dimensões: Comprimento aproximado, 5,6 $\mathrm{mm}$; comprimento das asa anterior, 5,08 $\mathrm{mm}$ (entre o ápice do esclerito Costal e o ápice da asa); largura máxima da cabeça, 2,03 mm; largura do abdômen, 2,3 mm.

Cor do integumento. Cabeça e tórax pardo-anegrados; escapo, mandíbulas, lóbulos pronotais, pernas e maior parte 


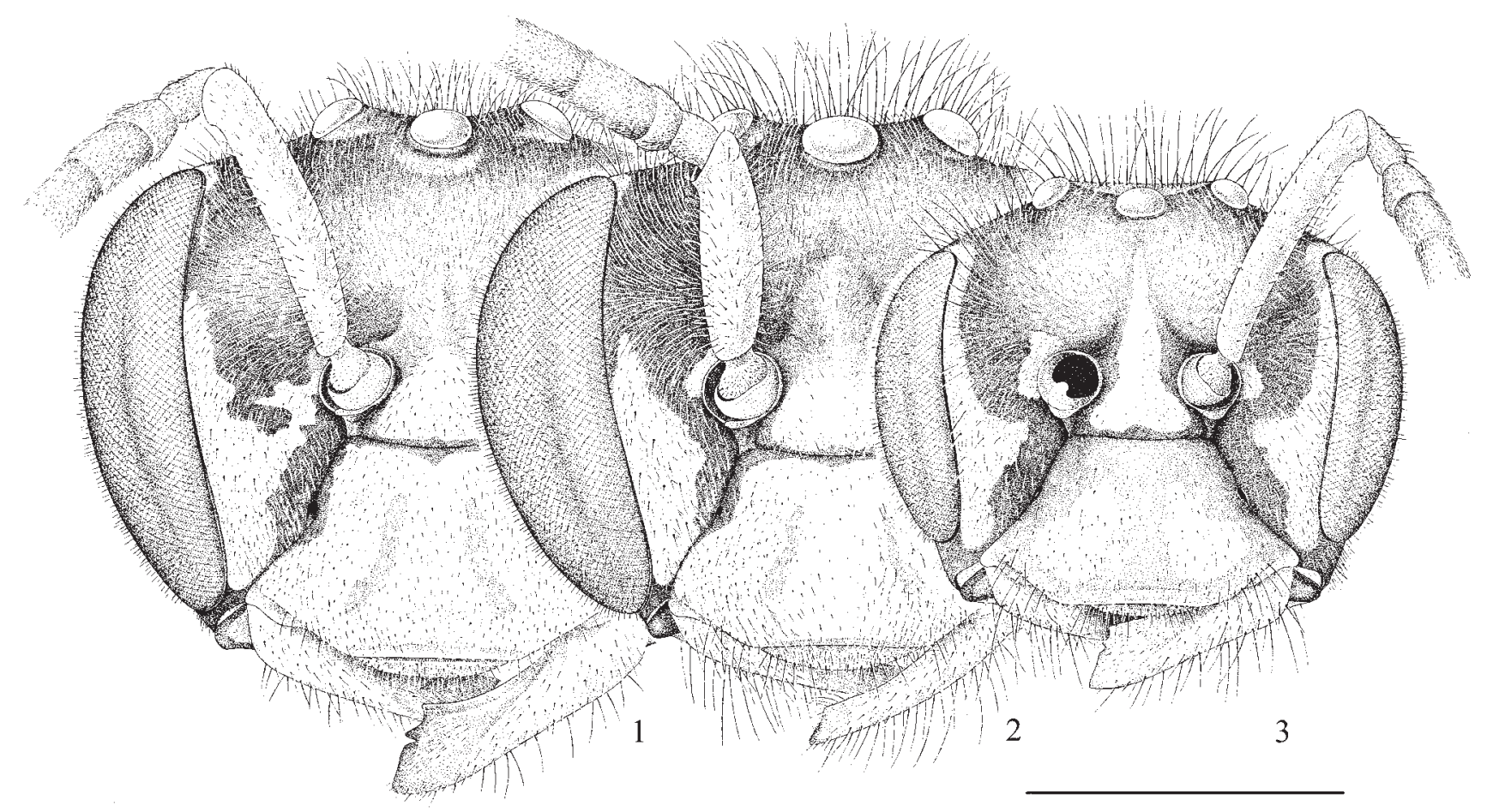

Figs. 1-3. Trichotrigona extranea (foz do rio Daraã, AM, Brasil). 1, operária; 2, macho; 3, rainha. Escala = 1,0 mm

do abdômen, ocráceo-ferrugíneos; flagelo pardacento; clípeo praticamente inteiro amarelado, exceto pela presença de duas vagas estrias pardas, uma de cada lado; desenhos amarelos nas áreas paroculares inferiores bem definidos, alargados embaixo e estreitados para cima, terminando ao nível da tangente superior dos alvéolos antenais; uma fina estria, da mesma cor dos desenhos na face, ao longo das órbitas posteriores até o vértice, nitidamente separadas das manchas paroculares; área supra-clipeal com desenho amarelo em forma de triângulo. Pronoto com faixa amarela vagamente interrompida no meio; as estrias laterais do mesoscuto estreitas e bastante encurtadas anteriormente; axilas e escutelo em grande parte pardos, como também larga faixa no segundo tergo abdominal; tégulas ocráceo-ferrugíneas nos dois terços posteriores, pardas no anterior; as asas lavadas de ferrugíneoocráceo com as veias maiores tingidas de pardo.

Pilosidade. Bem desenvolvida e predominantemente de cor ocráceo-ferrugínea; um pouco mais esparsa na fronte, disco do mesoscuto, mesepisternos e flancos do propódeo; notavelmente longa no abdômen, especialmente nos últimos segmentos. Olhos com pêlos curtos $(0,04 \mathrm{~mm})$, bem evidentes.

Integumento. Predominantemente liso e polido; pontuação pilígera e esparsa com intervalos maiores que os pontos ( 3 a 4 diâmetros).

Forma e proporções. Olho duas vezes e meia mais longo que largo (1,25:0,50); interorbital superior ligeiramente menor que a média e mais longa que a inferior, esta igualando ao comprimento do olho $(1,35: 1,44: 1,25)$; área malar muito estreita $(0,05)$; comprimento do clípeo cinco sétimos da distância clipeocelar $(0,65: 0,90)$; a distância interalveolar quase igual ao diâmetro do alvéolo, a alveolorbital aproximadamente o dobro da anterior e a alveolocelar lateral três vezes $(0,20: 0,22: 0,38: 0,63)$; distância interocelar um pouco maior que dois diâmetros do ocelo médio; a ocelorbital uma vez e meia esse diâmetro $(0,48: 0,20: 0,32)$; escapo longo, sobrepassando nitidamente o vértice; flagelo e pedicelo juntos, duas vezes mais longos que o escapo $(0,90: 1,80)$. Tíbia posterior perto de três vezes mais longa que sua largura máxima $(2,30: 0,80)$; o basitarso posterior um pouco mais longo que a largura da tíbia e cerca de duas vezes e meia a sua largura máxima $(0,88: 0,32)$, de lados subparalelos e com o ângulo posterior obtuso arredondado.

Sobre os exemplares da série-tipo. O holótipo, operária, e 16 parátipos da mesma casta, montados em alfinetes, e uma rainha e 26 operárias, preservadas em álcool $70 \%$, com etiqueta de "F. do R. Daraá, R. Negro, AM, Brasil, 2-4.VIII.1980, SA-20, $64^{\circ} 47^{\prime} \mathrm{W}, 0^{\circ} 25^{\prime}$ 'S, Camargo - Mazucato leg.", ninho "no $262 \mathrm{c}$ ", estão depositados na RPSP - Departamento de Biologia da Faculdade de Filosofia, Ciências e Letras de Ribeirão Preto USP (Coleção Camargo). Além destes, os seguintes parátipos, procedentes do mesmo ninho, se encontram depositados nas seguintes Instituições: 2 operárias no DZUP - Departamento de Zoologia, Universidade Federal do Paraná (Coleção Moure), 1 operária no STRI - Smithsonian Tropical Research Institute, Panamá (D. Roubik), 1 operária no SEMK - Entomology Division, Natural History Museum and Biodiversity Research Center, University of Kansas, Lawrence, USA, 1 operária no BLCU - National Pollinating Insect Collection, Bee Biology 

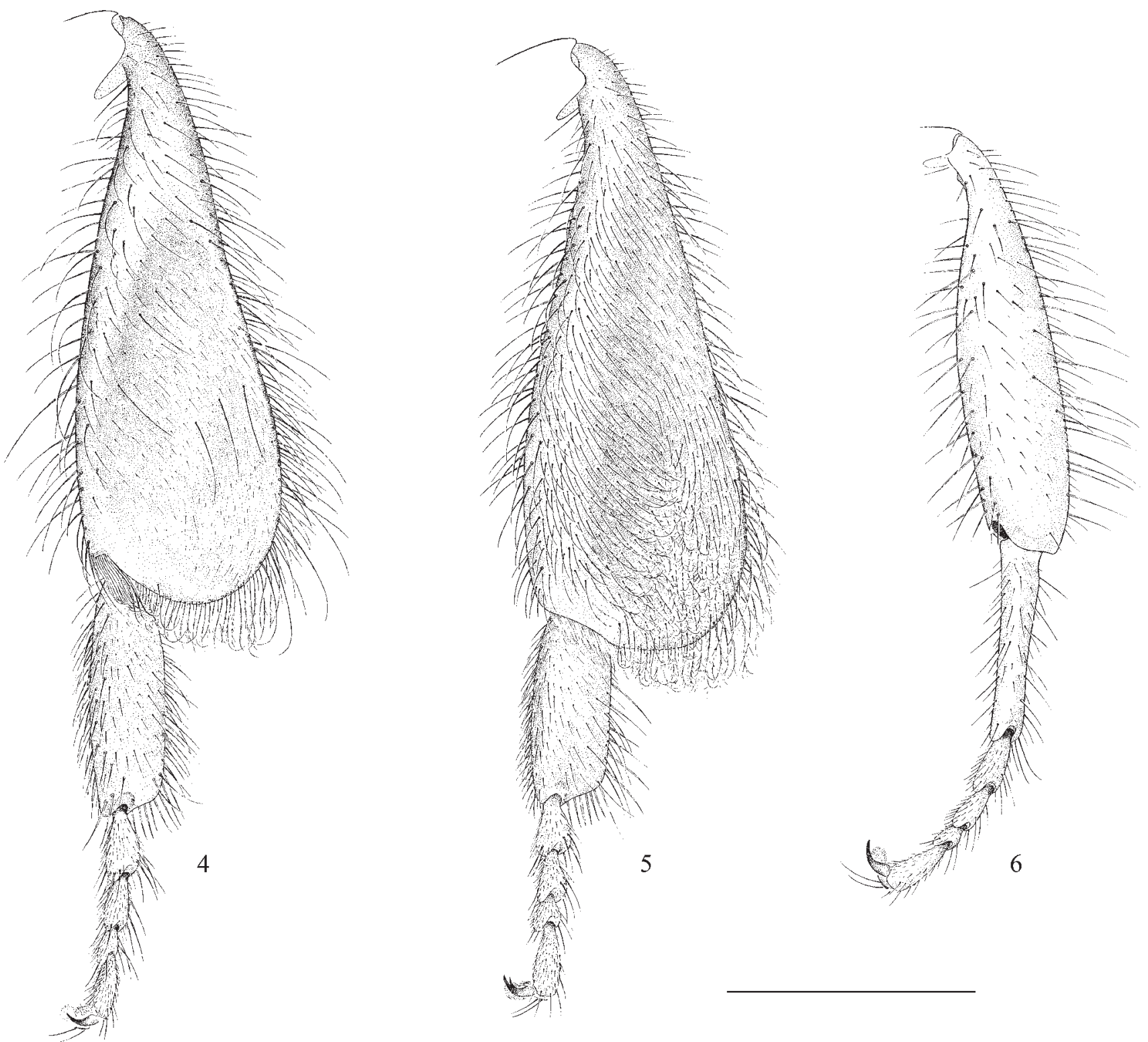

Figs. 4-6. Trichotrigona extranea (foz do rio Daraã, AM, Brasil), perna III. 4, operária; 5, macho; 6, rainha. Escala = 1,0 mm

and Systematics Laboratory, Utah State University, Logan, Utah, USA (por solicitação de P. F. Torchio) e 2 operárias na Hokkaido University, Sapporo, Japão (Coleção S. F. Sakagami).

Bionomia e notas sobre as rainhas e machos.

Hábitat e considerações gerais. Até agora, Trichotrigona somente foi encontrada numa pequena mata de igapó na foz do rio Daraã (644ㄱ'35"W, $\left.0^{\circ} 27^{\prime} 7^{\prime \prime} \mathrm{S}\right)$, afluente setentrional do médio rio Negro, AM, aproximadamente $30 \mathrm{Km}$ a jusante de Santa Isabel do Rio Negro (antiga Tapurucuara). O primeiro ninho (no de série: 262c) descoberto em 4.VIII.1980, estava situado em um pequeno oco de tronco seco, anexo a um ninho de Frieseomelitta paranigra, como já relatado por Camargo \& Moure (1983). Em julho-agosto de 1999, realizamos outra expedição ao rio Negro; nessa ocasião, já tendo indicação do substrato de nidificação preferido por T. extranea, concentramos nossas buscas nas árvores secas, tanto em terra firme como nos igapós, mas principalmente nestes, onde a quantidade de árvores mortas - secas (mortes naturais, mas principalmente pelo fogo ateado pelos ribeirinhos, durante os períodos de seca para obtenção de lenha) é muito grande (Fig. 8). Os ocos de troncos e ramos secos das árvores do igapó são intensamente habitados por várias espécies de Frieseomelitta; em uma única árvore, às vezes, pode-se encontrar agregações com dezenas de ninhos, de uma, duas ou várias espécies de Frieseomelitta. Como havia, também, a suspeita de que $T$. extranea pudesse ser um parasita social, as árvores com agregações de ninhos foram mais minuciosamente examinadas. As buscas se estenderam por cerca de 30 dias, ao longo do trecho entre a foz do rio Curicuriari (66 $\left.66^{\circ} 7^{\prime} 36^{\prime \prime} \mathrm{W}, 0^{\circ} 12^{\prime} 13^{\prime \prime} \mathrm{S}\right)$, no alto rio Negro, até a foz do rio Daraã, em nove pontos de 
coleta. Centenas de árvores foram examinadas, principalmente na localidade de Carixeno (65⒌' $57^{\prime \prime} \mathrm{W}, 0^{\circ} 20^{\prime}$ 'S) e na foz do rio Uneiuxi (65'5'57"W, 0³4'45"S), onde os igapós são mais extensos e, nessa época do ano (julho-agosto), de rio cheio (3 a $5 \mathrm{~m}$ acima do nível do período seco), pode-se transitar, facilmente, de canoa, por entre as árvores e examinar mais detalhadamente as partes mais altas dos troncos e ramos. Centenas de ninhos de Frieseomelitta e de espécies de outros gêneros de Meliponini foram encontrados, mas nenhum de $T$. extranea. Finalmente, retornamos à foz do rio Daraã (Fig. 8), exatamente no mesmo local onde o primeiro ninho havia sido encontrado em 1980. Aí, em três dias de buscas, outros três ninhos foram encontrados ( $\mathrm{n}^{\mathrm{o}} \mathrm{s}$. de série 800c, 806c e 807c), todos em ramos secos de árvores vivas de Buchenavia suaveolens Eichler (Combretaceae), planta muito comum nas areias brancas dos igapós, e conhecida pelo nome de "Tanimbuca"; produz madeira dura, pesada, densa e muito resistente às intempéries. Os pequenos ocos no interior dos ramos, parecem ser o resultado da lenta decomposição natural, e não da ação de brocas, como lagartas de mariposas e de coleópteros.

Ninho. O ninho 800c estava instalado em um ramo com 6 $\mathrm{cm}$ de diâmetro externo, com a entrada situada a ca. 1,80 m acima do nível de cheia do rio (Fig. 8); era solitário, ou seja, não havia qualquer outro ninho de Meliponini compartilhando o mesmo oco, nem em qualquer outro ramo da árvore. Os ninhos $806 \mathrm{c}$ e $807 \mathrm{c}$, distantes ca. $300 \mathrm{~m}$ do primeiro (800c), estavam instalados em 2 ramos secos de uma mesma árvore de "Tanimbuca", a 1,50 e 1,80 m acima do nível da cheia; estes, porém, ocupavam ocos em comum com ninhos de Frieseomelitta sp. (=F. modesta Moure, $n$. nud., in Camargo $\&$ Pedro 2003) (Figs. 9, 10).

O oco ocupado pelo ninho $800 \mathrm{c}$, media $43,5 \mathrm{~cm}$ de comprimento por 1,0-2,3 cm de diâmetro e bastante irregular; em cima, vedando a parte exposta do oco, havia um pequeno batume composto de partículas vegetais cimentadas com resinas enegrecidas, formando uma estrutura irregular dura e quebradiça, com ca. $2 \mathrm{~mm}$ de espessura; embaixo, o oco terminava em um fundo cego. O espaço do oco ocupado pelo ninho $806 \mathrm{c}$, media $41 \mathrm{~cm}$ de comprimento por $1,5-2,5 \mathrm{~cm}$ de diâmetro (Fig. 10), e o do ninho $807 \mathrm{c}, 90 \mathrm{~cm}$ de comprimento por 2,0-3,0 cm de diâmetro; ambos delimitados, em cima e embaixo, por batumes como aquele do ninho $800 \mathrm{c}$, porém incorporando partículas de areia, variando de 0,3 a $1,0 \mathrm{~cm}$ de espessura. No mesmo oco (que tinha, ao todo, ca. $4.0 \mathrm{~m}$ de extensão) em que estava instalado o ninho 806c, havia 3 ninhos de Frieseomelitta sp. (Fig. 9); o de T. extranea ficava entre dois deles (um em cima e dois embaixo), dos quais se separava apenas pelos finos batumes em comum (Fig. 10). Na parte inferior do ninho 807c, também havia um ninho da mesma espécie de Frieseomelitta, sem qualquer espaço entre eles, apenas separados pelo pequeno batume de resinas. Não sabemos se os batumes em comum são construídos por operárias de ambas as espécies ou por apenas uma delas, o fato é que são idênticos, mesmo quando elas não constróem

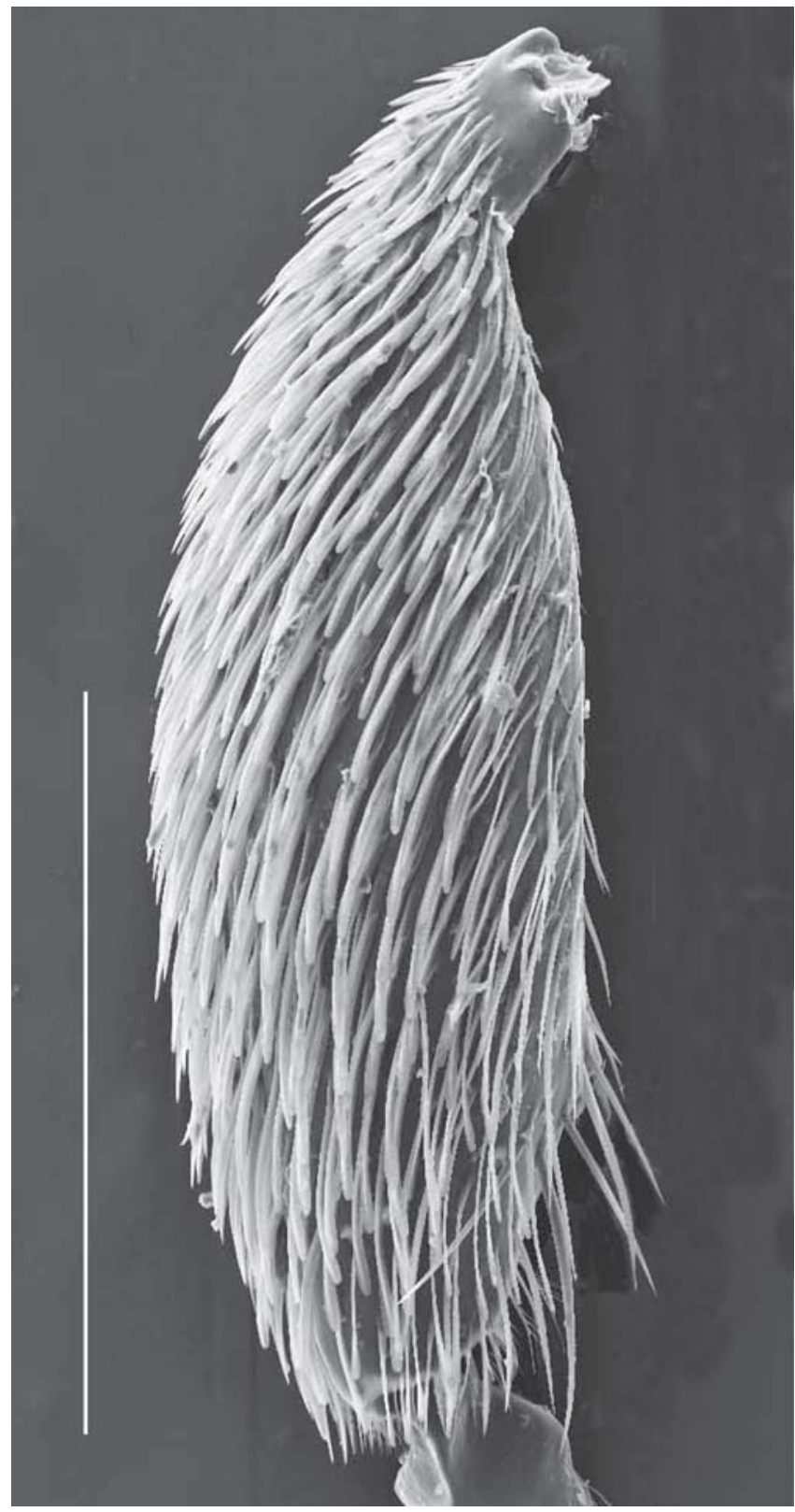

Fig. 7. Trichotrigona extranea (foz do rio Daraã, AM, Brasil), tíbia I da operária. Escala $0,5 \mathrm{~mm}$

ninhos vizinhos. As paredes dos ocos também revestidas por finas aplicações de resinas enegrecidas, como que envernizadas; na parte inferior, bastantes amareladas aparentemente as abelhas defecam dentro do ninho e as exinas são incorporadas à resina do revestimento.

O ninho 800c continha um pequeno depósito de resinas, com menos de $1 \mathrm{~cm}^{3}$, mas os outros dois ninhos continham largos depósitos de resinas pretas, mescladas de amarelo, muito pegajosas, fixadas nas paredes do oco; no ninho 806c havia um depósito com ca. $2 \mathrm{~cm}^{3}$ (Fig.10), e no 807c, dois depósitos, somando mais de $3 \mathrm{~cm}^{3}$. Quando dissolvidas em acetona ou éter, essas massas de resinas revelaram grande quantidade de grãos de pólen, grãos de areia e partículas vegetais, havia 


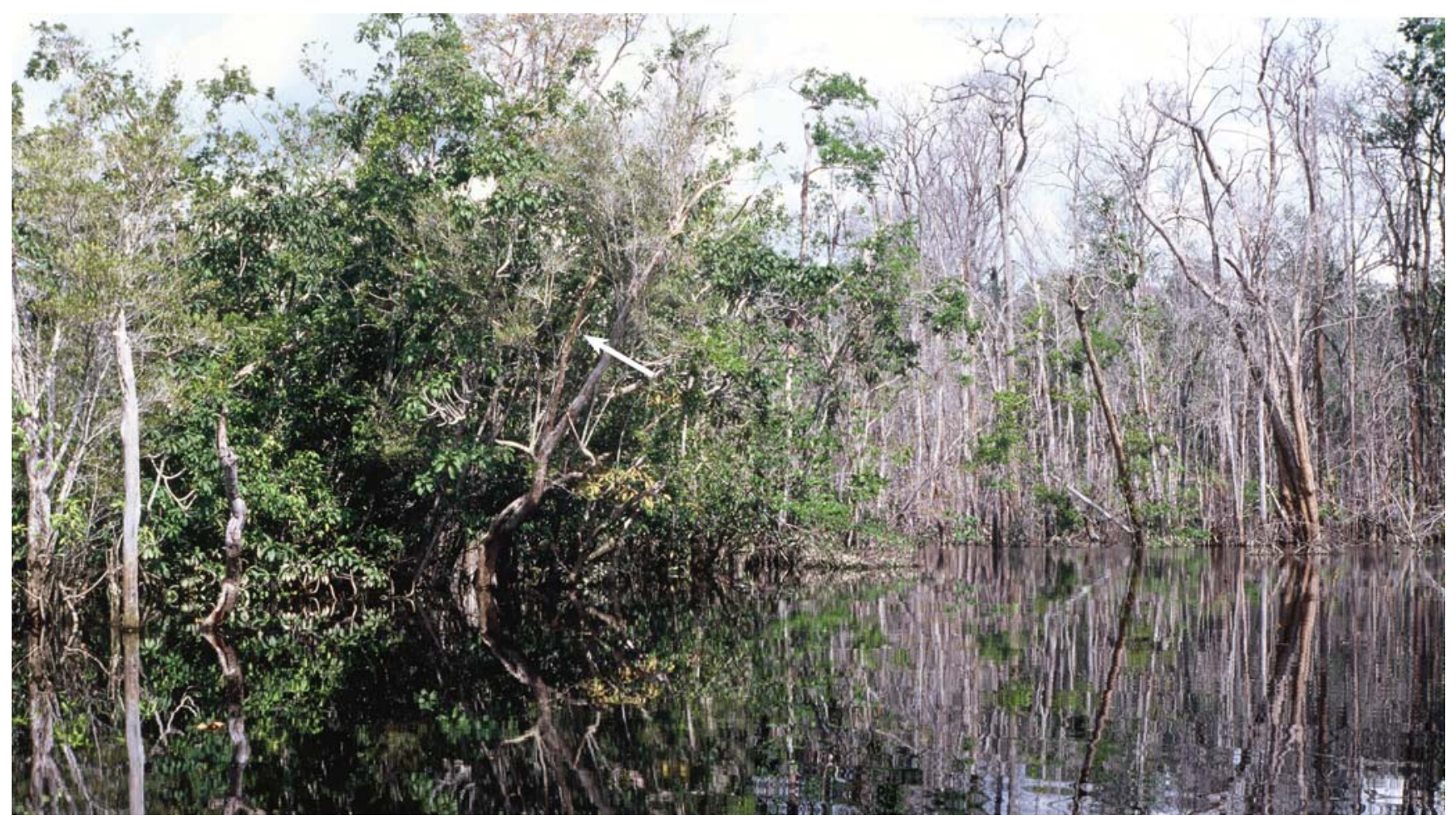

Fig. 8. Mata de igapó na foz do rio Daraã, AM, Brasil; a seta indica uma árvore de "Tanimbuca" (Buchenavia suaveolens Eichler), onde foi encontrado um dos ninhos de Trichotrigona extranea (ninho 800c)

também muitos fragmentos e alguns corpos inteiros de insetos, principalmente formigas.

Entrada do ninho - um orifício com ca. 3,5 mm de diâmetro, apenas delimitado com resinas pardo-enegrecidas. No ninho $807 \mathrm{c}$, o orifício era rodeado por um volume um pouco maior de resinas, partículas vegetais e areia (Fig. 11), formando uma massa com ca. $4,0 \mathrm{~cm}$ de altura por $1,5 \mathrm{~cm}$ de largura. Internamente, o orifício dava acesso diretamente ao oco, não havia qualquer galeria. A superfície do tronco, ao redor da entrada, não recebe qualquer tratamento, como é comum em algumas espécies de Frieseomelitta, que fazem grandes aplicações de resinas pegajosas e partículas de areia.

Potes de armazenagem - Não havia nenhum pote, nem de pólen nem de mel, em nenhum dos ninhos. Apenas no 806c, havia uma pequena câmara ovalada, com ca. $0,8 \times 1,0 \mathrm{~cm}$, de paredes cerosas, irregulares, finas e de cor âmbar, porém inteiramente vazia. Essa câmara mais se assemelhava a uma cela de prisão de rainhas (como aquela de Schwarziana quadripunctata Lepeletier, 1836, $c f$. Camargo, 1974) do que a um pote de armazenar alimento; além disso, havia uma pequena abertura lateral, e não no topo (Fig. 10a).

Células de cria - Distribuídas em forma de cacho, como nas espécies de Frieseomelitta, com as paredes anexas umas às outras, formando pequenos conjuntos fixados às paredes do oco por meio de finos conectivos de cerume (Figs. 10, 12, 13). No ninho 807c, em um dos conjuntos, as células estavam relativamente alinhadas, lembrando, vagamente, um favo irregular em espiral (Fig. 12). Não havia invólucro ou qualquer outra estrutura ao redor dos conjuntos de células. Os casulos são ovais, medindo, aproximadamente, 4,30x6,24 mm. As células novas são mais arredondadas, com ca. 4,60-4,85 mm de diâmetro, por 6,05-6,80 mm de altura; aparentemente são constituídas de cera pura, com as paredes um pouco irregulares, com ca. 0,48 mm de espessura. Uma célula contendo pupa de rainha praticamente não se distinguia das de operárias (não foram abertos todos os casulos para verificar a eventual presença de outras rainhas). O suprimento das células era constituído, em grande parte, de pólen - de vários tipos - , misturados a uma massa amorfa gelatinosa (o exame foi feito em material fixado).

Os seguintes tipos polínicos foram encontrados em amostras de alimento obtidas em três células de cria de $T$. extranea (dados originais em Absy et al. 2006): Eschweilera sp. (Lecythidaceae) - 45\%, Leguminosae - 12\%, Cordia sp. (Boraginaceae) - 10\%, Mabea nitida (Euphorbiaceae) - 7\%, Myrtaceae - 7\%, Theobroma cacao (Sterculiaceae) - 6\%, Rubiaceae - 6\%, Buchenavia sp. (Combretaceae) $-4 \%$, Didymopanax sp. (Araliaceae) - 3\%, e, com valores inferiores a 3\%, Rhodognaphalopsis minor (Bombacaceae), Acacia polyphylla (Mimosaceae), Amanoa sp. (Euphorbiaceae), Pachira aquatica (Bombacaceae), Compositae, Inga sp. (Mimosaceae), Pseudobombax mumguba (Bombacaceae), Attalea maripa (Arecaceae), Poaceae, Alchornea sp. (Euphorbiaceae), Theobroma grandiflorum (Sterculiaceae) e Tapirira guianensis (Anacardiaceae). 


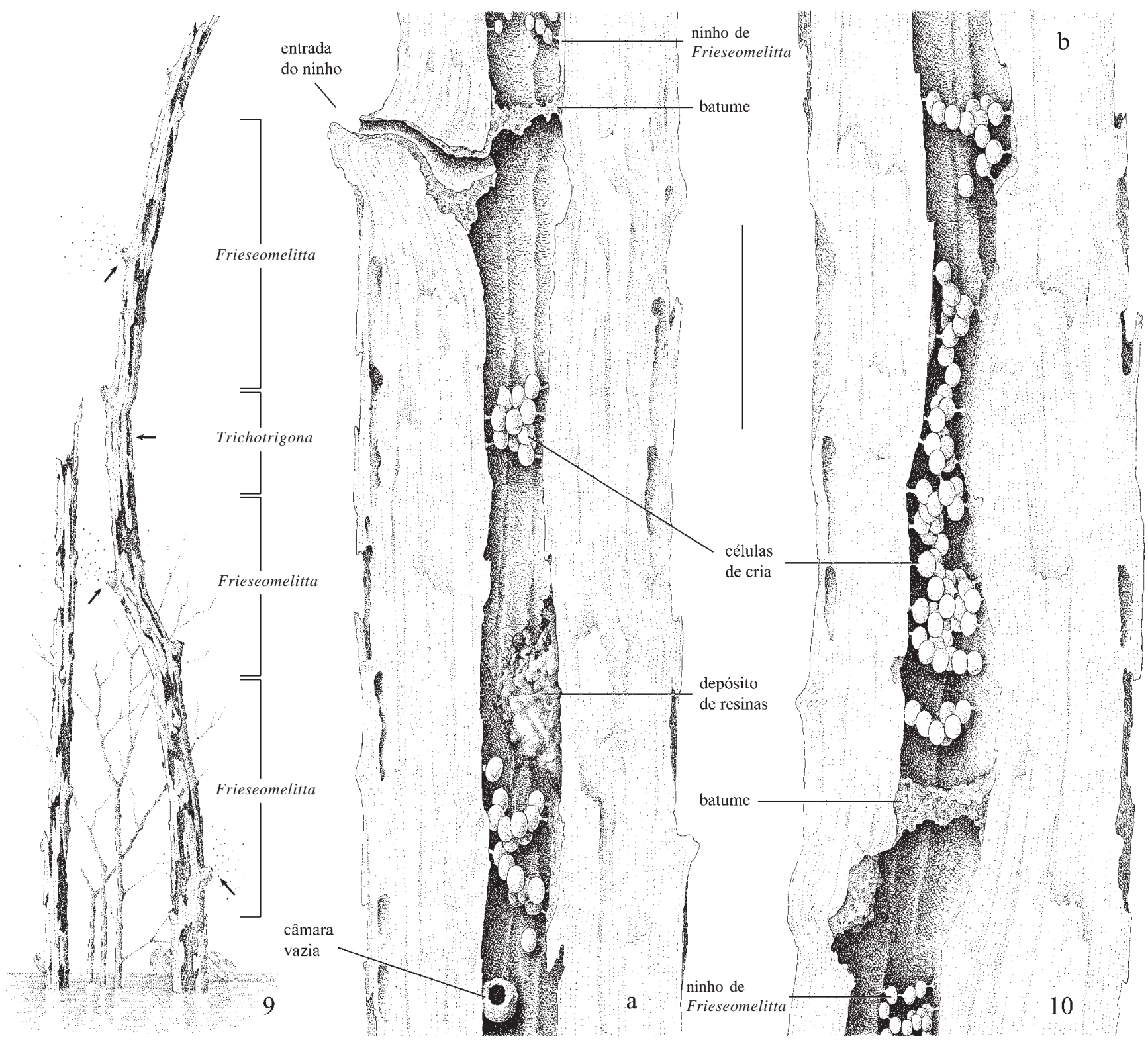

Figs. 9-10. Ninho de Trichotrigona extranea (ninho 806c, foz do rio Daraã, AM, Brasil) em ramo de "Tanimbuca" (Buchenavia suaveolens Eichler). 9, localização, entre três ninhos de Frieseomelitta sp.; as setas indicam as entradas, e as chaves, a extensão dos ninhos; 10, corte longitudinal - as letras a e b indicam a sequiência das partes. Escala $=5 \mathrm{~cm}$

População - O ninho 800c continha 46 células, todas novas, com ovos, embriões, larvas pré-defecantes de várias idades e algumas em fase de defecação, com o casulo já tecido. Não havia nenhuma pupa. A população adulta constituía de 43 operárias e uma rainha fisogástrica, com as asas sem nenhum desgaste. Não havia machos - tratava-se certamente de um ninho novo e, aparentemente, essa é a população fundadora.

O ninho 806c continha ca. 240 células, das quais, ca. 60 novas, com ovos, embriões e larvas pré-defecantes de várias idades; as demais (ca. 180), com larvas pós-defecantes até pupas pigmentadas. A população adulta com ca. 143 indivíduos - uma rainha fisogástrica, 25 machos e 117 operárias.
O ninho 807c continha ca. 260 células, das quais ca. 60 novas, com ovos, embriões e larvas pré-defecantes de várias idades; as demais (ca. 200), com o casulo já tecido, com larvas pós-defecantes e pupas de várias idades, inclusive uma pupa de rainha. A população adulta constituía de uma rainha fisogástrica e 163 operárias. Não havia machos. Supõem-se que todos os ninhos estavam com sua população completa, visto que nenhum movimento de abelhas foi observado fora destes.

Comportamento - Nos três ninhos observados, sempre havia uma única operária de "guarda", fechando praticamente todo o orifício de entrada com a cabeça. Nenhum movimento de abelhas foi notado em ca. de $1 \mathrm{~h}$ de observação no ninho 

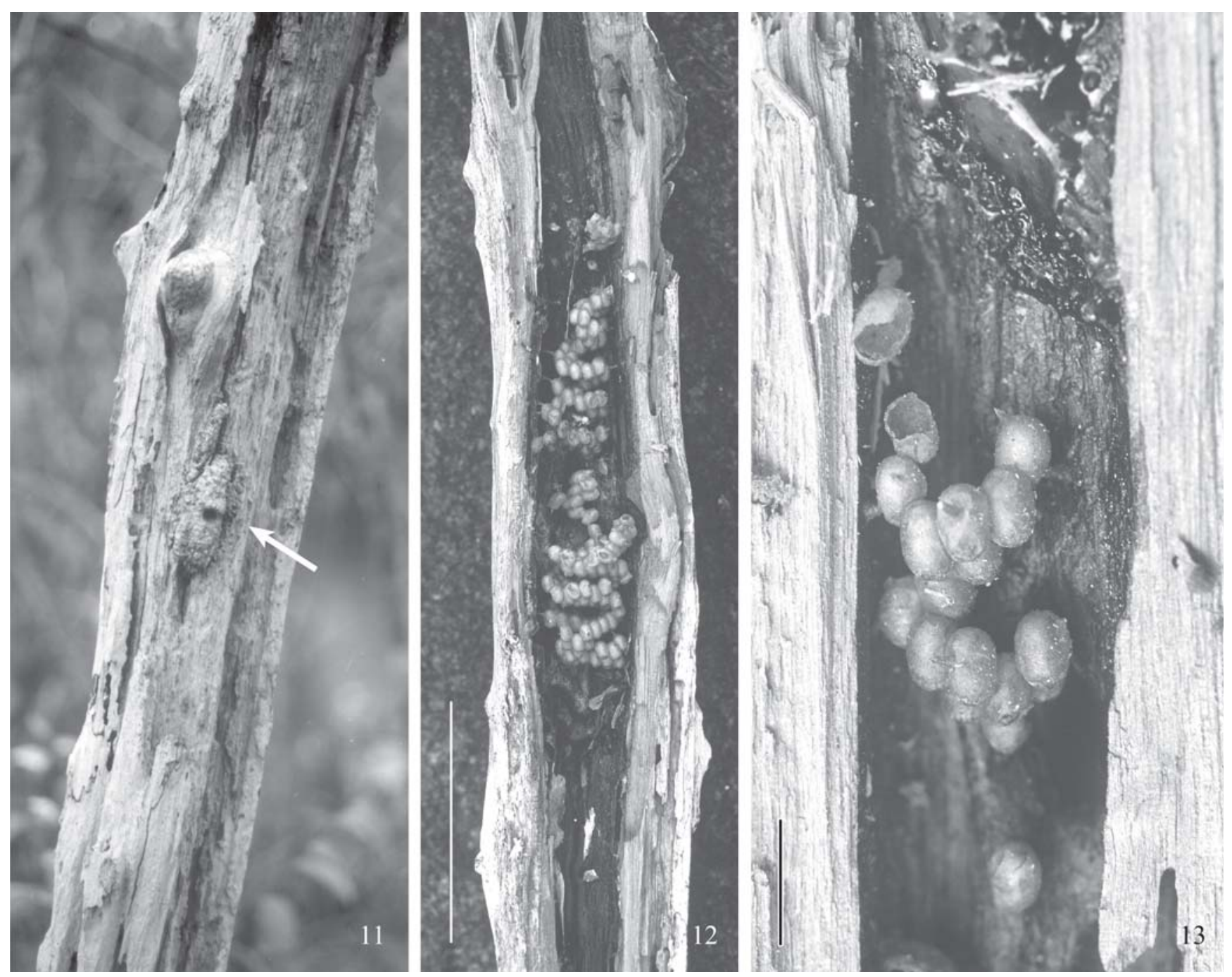

Figs. 11-13. Trichotrigona extranea (foz do rio Daraã, AM, Brasil). 11-12, ninho 807c, detalhe da entrada e corte longitudinal. Escala $=10 \mathrm{~cm}$; 13, ninho 806c, detalhe das células de cria e depósito de resinas. Escala $=1 \mathrm{~cm}$

800c, porém, com alguns toques na madeira, com a lâmina de uma faca, duas abelhas saíram em vôo rápido; uma delas retornou à entrada após alguns minutos. O mesmo procedimento foi repetido nos outros ninhos, provocando a saída de 3-4 abelhas; uma delas foi ao cabelo do observador, mas não mordeu. Outro fato que merece registro, é a grande resistência das abelhas ao éter sulfúrico. Para abrir os ninhos, sem perda da população adulta, o éter foi soprado, várias vezes, para o interior deles, através do orifício de entrada, mas as abelhas não ficavam totalmente dormentes; foi necessário acrescentar um pouco de acetato de etila para se obter o efeito desejado.

Das 168 operárias examinadas (exemplares dos três ninhos, já montados em alfinetes), 46 delas continham, na "corbícula", da tíbia III, cargas de grãos de areia, partículas vegetais em decomposição, fragmentos de carvão e outros fragmentos orgânicos amorfos e grãos de pólen e resinas misturados. Algumas dessas cargas chegavam a ser bastante volumosas, ocupando toda a superfície externa da tíbia. Dos 18 machos examinados, dois também continham cargas na tíbia III idênticas àquelas das operárias. Muitas das operárias também apresentavam a "escova" de cerdas da face interna do basitarso III, toda empastada de partículas vegetais, grãos de areia e grãos de pólen. Todavia, nenhuma operária apresentava carga de pólen (puro) na tíbia III; apenas algumas delas apresentavam massas de pólen espalhadas pela cabeça (na região hipostomal) e tórax (talvez regurgitado). A tíbia I das operárias (que é intumescida e revestida por cerdas robustas e com as pontas espatuladas, e supostamente com alguma função especial), também foi examinada em todos os exemplares, mas nada se encontrou além de alguns raros grãos de pólen aderidos entre as cerdas.

Algumas operárias (daquelas conservadas em álcool) também foram dissecadas para verificar o conteúdo do papo. Naquelas bem jovens ainda não totalmente pigmentadas e em pupas de olhos escuros retiradas das células, o papo estava literalmente cheio de pólen (sem dúvida, pólen remanescente do período de alimentação larval). Alguns indivíduos bem 
pigmentados, e que provavelmente já tinham voado para fora do ninho, tinham o papo praticamente vazio, apenas com algum pólen; contudo, no ventrículo e no reto havia pólen e exinas.

Rainha (Figs. 3, 6) - Foram examinadas quatro rainhas fisogástricas (inclusive aquela obtida em 1980, do ninho 262c) e uma pupa. No que se refere à cor, estrutura do tegumento e pilosidade, é como nas operárias; apenas no vértice as cerdas são um pouco mais longas e no abdômen um pouco mais curtas; cerdas plumosas são praticamente ausentes - mais evidentes apenas no lóbulo pronotal e ao redor do espiráculo propodeal. Na tíbia I as cerdas são simples, e não espatuladas como nas operárias. A cabeça e o tórax são bem menores que nas operárias; enquanto nas rainhas a cabeça mede $1,60 \mathrm{~mm}$ de largura e o mesoscuto, entre as tégulas, $1,25 \mathrm{~mm}$, nas operárias medem, respectivamente, ca. 2,04 e 1,60 mm (medidas da rainha na Tab. 1). No comprimento total do corpo se equivalem, em torno de $6,0 \mathrm{~mm}$, quando a operária é comparada com a rainha virgem; a rainha fisogástrica, e com o abdômen mais dilatado, chega a medir cerca de $7.0 \mathrm{~mm}$. O basitarso III é muito longo, cerca de metade do comprimento da tíbia, estreito e cilíndrico (Fig. 6). A cada lado do tergo abdominal IV (3o metassomático), há um pequeno conjunto de poros, relativo a abertura das glândulas tegumentares.

Os ovários são muito longos; quando distendidos, eqüivalem a cerca de três vezes o comprimento do abdômen; cada um é constituído de quatro ovaríolos. Em cada ovário há 3-4 oócitos praticamente prontos para a postura.

A glândula de Dufour é relativamente grande, com cerca de $1,3 \mathrm{~mm}$ de comprimento, quando distendida, por cerca de $0,03 \mathrm{~mm}$ de largura; um pouco menor que a glândula de Frieseomelitta freiremaiai Moure, 1963, descrita por Kerr \& Lello (1962).

Macho (Figs. 2, 5) - Como nas operárias no que se refere a cor do corpo, desenhos amarelos da cabeça e tórax e estrutura do integumento - muito liso e brilhante; no vértice, as cerdas um pouco mais longas (de até $0,33 \mathrm{~mm}$ ); na tíbia I as cerdas são simples, e não espatuladas como nas operárias; na tíbia III cerdas longas (as mais longas com cerca de $0,45 \mathrm{~mm}$ ) e finas revestem toda a superfície externa e, no quarto distal, são sinuosas e ramificadas apicalmente. No abdômen, as cerdas são mais escassas, porém simples e tão longas como nas operárias (as mais longas com cerca de $0,52 \mathrm{~mm}$ ).

Cabeça 1,20 x mais larga que longa e 2,50 vezes mais larga que a distância clipeocelar. Olhos 2,08 vezes mais longos que largos e levemente convergentes embaixo. Área malar linear. Clípeo 0,62 vezes mais curto que sua largura máxima e cerca de 0,80 vezes a distância clipeocelar. Mandíbula tão longa quanto a distância clipeocelar, com pequeno dentículo no canto interno. Labro normal, apenas com uma leve reentrância mediana distal. Escapo 1,14 vezes a distância alveolocelar lateral. O $1^{\circ}$ flagelômero curto, cerca de 0,66 vezes sua largura. Distância interocelar 2,04 vezes maior que a ocelorbital e 2,13 vezes o diâmetro do ocelo médio. Escutelo 1,86 vezes mais largo que longo. Tíbia III praticamente idêntica a da operária na forma, comprimento e largura $-2,92$ vezes mais longa que
Tabela I. Medidas ( $\mathrm{mm}$ ) da rainha e macho de Trichotrigona extranea.

\begin{tabular}{lcc}
\hline Variáveis & Rainha & Macho \\
\hline Cabeça, largura máxima & 1,60 & 1,93 \\
Cabeça, comprimento & 1,28 & 1,61 \\
Olho, comprimento & 0,89 & 1,29 \\
Olho, largura & 0,36 & 0,62 \\
Interorbital superior & 1,11 & 1,29 \\
Interorbital máxima & 1,19 & 1,35 \\
Interorbital inferior & 1,08 & 1,08 \\
Ocelo médio, diâmetro & 0,16 & 0,23 \\
Interocelar, entre os ocelos laterais & 0,39 & 0,49 \\
Ocelorbital & 0,26 & 0,24 \\
Interalveolar & 0,19 & 0,26 \\
Alveolorbital & 0,28 & 0,28 \\
Alvéolo, diâmetro & 0,17 & 0,22 \\
Clípeo, comprimento & 0,49 & 0,61 \\
Clípeo, largura máxima & 0,95 & 0,99 \\
Área malar, comprimento & 0,09 & 0,02 \\
Escapo, comprimento & 0,84 & 0,72 \\
Escapo, diâmetro & 0,13 & 0,18 \\
Pedicelo + flagelo, comprimento & 1,69 & 2,41 \\
Flagelômero 1, comprimento & 0,15 & 0,10 \\
Flagelômero 2, comprimento & 0,14 & 0,25 \\
Flagelômero 3, comprimento & 0,15 & 0,23 \\
Flagelômero 3, diâmetro & 0,11 & 0,15 \\
Mandíbula, comprimento & 0,74 & 0,78 \\
Asa anterior, comprimento (entre o & 3,95 & 5,08 \\
esclerito Costal e a ponta da asa) & & \\
Asa anterior, comprimento (incluindo a & 4,54 & 5,66 \\
tégula) & & \\
Asa anterior, largura & 1,56 & 1,92 \\
Mesoscuto, largura (entre as tégulas) & 1,25 & 1,48 \\
Mesoscuto, comprimento & 0,84 & 1,29 \\
Escutelo, largura & 0,84 & 0,95 \\
Escutelo, comprimento & 0,42 & 0,51 \\
Tíbia III, comprimento & 1,65 & 2,34 \\
Tíbia III, largura & 0,40 & 0,80 \\
Basitarso III, comprimento & 0,76 & 0,70 \\
Basitarso III, lagura & 0,11 & \\
\hline & & \\
& & \\
& & \\
& &
\end{tabular}

larga -, com o quarto distal levemente côncavo, lembrando a forma de uma corbícula. Forma do basitarso III também como na operária, apenas mais curto - 2,33 vezes mais longo que largo. Asas, como na operária (mensurações na Tab. I). A genitália e esternos pré-genitais foram figurados por Camargo \& Pedro (2003).

\section{DISCUSSÃO}

O fato de que Trichotrigona não constrói potes e não armazena qualquer tipo de alimento - pelo menos não em potes - em adição à perda de estruturas associadas à coleta e manipulação do pólen (perda do pente de pólen e redução do penicilo), corrobora a hipótese de parasitismo. Todavia, não de parasitismo-social, como sugerido por Roubik (1989: 255) e Michener (1990: 128; 2000: 799). A idéia por trás desse 
raciocínio, é a de que Trichotrigona pudesse ter acesso a ninhos vizinhos (anexos, no mesmo oco) de outros Meliponini (espécies de Frieseomelitta, supostamente), através do batume de separação, para obter alimento; mas essa idéia não encontra respaldo nas observações de campo. Primeiro, o total da população encontrada dentro dos ninhos era exclusivamente de Trichotrigona, e não havia qualquer vestígio (estrutural, fragmentos de corpo, etc.) que indicasse uma associação com ninhos vizinhos de outras espécies de Meliponini, além disso, os batumes de separação eram bem rígidos e compactos. Segundo, embora dois dos ninhos estudados (três, se considerarmos o de no $² 62$ c, estudado em 1980) estivessem anexos a ninhos de Frieseomelitta spp., um

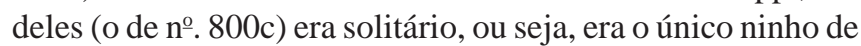
Meliponini que havia na árvore; fato que também exclui a idéia de associação acima sugerida.

Por outro lado, os atributos acima relacionados, aliados a características tais como: porte corporal robusto (se comparado a Frieseomelita spp), integumento liso e recoberto com cerdas setáceas simples e esparsas, resistência (inferida pela resistência ao éter sulfúrico), e ao fato de que aprovisionam as células de cria com pólen (uma grande diversidade de tipos polínicos, embora não armazenem esse produto, e nem haja evidências de que o coletem diretamente nas flores), indicam, possivelmente, para uma atividade cleptobiótica. Mas não ao estilo das espécies de Lestrimelitta.

As espécies de Lestrimelitta possuem ninhos com milhares de indivíduos, e quando invadem ninhos de outros Meliponini, o fazem com grande número de operárias e em ataques maciços, delapidando rapidamente todo o estoque de pólen, mel e provisões de crias do hospedeiro, que são transportados no papo e armazenados em seus próprios ninhos. O material de construção é levado na tíbia III. Podem morrer muitas operárias nesses ataques (Sakagami et al. 1993).

Diferentemente, a população dos ninhos de Trichotrigona é muito pequena; o ninho maior, mais populoso, tinha 163 operárias e o menor 43, obviamente um número muito pequeno para se suspeitar de um comportamento equivalente ao de Lestrimelitta. Se de fato são cleptobióticas, resta supor que as abelhas agem individualmente, ou seja, que tenham acesso individual, livre e contínuo aos recursos dos ninhos dos eventuais hospedeiros, supostamente espécies de Frieseomelitta, que são muito comuns na região e têm os mesmos hábitos de nidificação que Trichotrigona.

Quanto aos grãos de pólen encontrados misturados nas cargas de detritos, grãos de areia e resinas, transportados pelas operárias e alguns machos, supostamente são obtidos no chão, juntamente com os detritos, provavelmente nas areias das margens dos igapós, onde muito pólen trazido pela água e pelo vento pode ficar depositado. Não há nenhum indício de que esses grãos de pólen possam ser utilizados na alimentação de Trichotrigona; no ninho, são encontrados misturados nos depósitos de resinas e nos batumes. É plausível especular que essas cargas de detritos, associados com resinas, transportados pelas abelhas possam servir como "camuflagem" para ingresso nos ninhos de eventuais hospedeiros. Frieseomelitta sp. (F. modesta Moure, n. nud.), que é muito abundante na região do médio rio Negro, tem, também, o hábito de coletar detritos, especialmente grãos de areia, que são intensamente aplicados, misturados com resinas, na superfície do tronco ao redor do orifício de entrada.

Quanto às cerdas espatuladas da tíbia I, não temos ainda qualquer idéia para que servem.

Por fim, embora alguns aspectos interessantes sobre o modo de vida de Trichotrigona tenham sido esclarecidos, o mais importante, que se refere ao alimento - onde e como o obtém - permanece obscuro.

Agradecimentos. Ao Sr. Menderson Mazucato, que descobriu os ninhos aqui descritos. Ao INPA, por haver cedido o barco "Uiara", para a viagem de 1999 ao rio Negro, e à tripulação. À Dra. Inês de Paula Miranda (INPA) pela identificação das plantas hospedeiras dos ninhos; à Dra. Maria Lúcia Absy por estudar as amostras de pólen e Claus Rasmussen (University of Illinois at Urbana-Champaign, USA) pelas fotos no microscópio de varredura

\section{REFERÊNCIAS}

Absy, M. L.; J. M. F. Camargo \& O. S. Santos. 2006. Diversidade polínica em amostras de duas espécies de abelhas sem ferrão (Scaptotrigona sp. e Trichotrigona extranea Camargo \& Moure, 1983) na região da Amazônia Central, 3 pp. In: Anais do XVI Congresso Brasileiro de Apicultura, 50 Anos de Abelhas Africanizadas e II Congresso Brasileiro de Meliponicultura, Aracaju, Sergipe, Editora Imagem, publicação em mídia digital.

Camargo, J. M. F. 1974. Notas sobre a morfologia e biologia de Plebeia (Schwarziana) quadripunctata quadripunctata (Hym. Apidae). Studia Entomologica 17: 433-470.

Camargo, J. M. F. \& J. S. Moure. 1983. Trichotrigona, um novo gênero de Meliponinae (Hymenoptera, Apidae) do Rio Negro, Amazonas, Brasil. Acta Amazonica 13: 421-429.

Camargo, J. M. F. \& S. R. M. Pedro. 2003. Sobre as relações filogenéticas de Trichotrigona Camargo \& Moure (Hymenoptera, Apidae, Meliponini). In G. A. R. Melo \& I. Alves-dos-Santos, Apoidea Neotropica: Homenagem aos 90 anos de Jesus Santiago Moure. Editora UNESC, Criciúma: pp. 109-122.

Kerr, W. E. \& E. Lello. 1962. Sting glands in stingless bees - a vestigial character (Hymenoptera: Apidae). Journal of the New York Entomological Society 70: 190-214.

Michener, C. D. 1990. Classification of the Apidae (Hymenoptera). The University of Kansas Science Bulletin 54: 75-164.

Michener, C. D. 2000. The Bees of the World. Baltimore, Johns Hopkins University Press, xiv +913 p.

Roubik, D. W. 1989. Ecology and Natural History of Tropical Bees. New York, Cambridge University Press, $x+514$ p.

Sakagami, S. F.; D. W. Roubik \& R. Zucchi. 1993. Ethology of the robber stingless bee, Lestrimelitta limao (Hymenoptera, Apidae). Sociobiology 21: 237-277. 